TURIZAM

Volume 20, Issue 3 105-127 (2016)

ORIGINAL SCIENTIFIC PAPER

\section{Mosque-Visiting: Motivations and Experiences of Non-Muslim Visitors at the Al-Azhar Mosque in Egypt}

\author{
Ahmed Abdel Fattah ${ }^{A^{*}}$, Mary E. Eddy-U ${ }^{\mathrm{A}}$ \\ Received: August 2016 | Accepted: September 2016 \\ DOI: 10.18421/TRZ20.03-01
}

\begin{abstract}
Mosque-visiting is a form of religious tourism worthy of special consideration due to the intense, mainly negative, media attention to Islam around the world. Despite a long scholarly tradition of looking at the relationship between Islam and tourism, the topic of non-Muslim visitors' motivations and experiences in visiting mosques has not been researched. Therefore, this paper explores non-Muslim visitors' motivations and experiences when visiting Al-Azhar mosque in Egypt. This paper presents the findings of semi-structured interviews with twenty six non-Muslim visitors. Three key themes were revealed of commonly reported motives and experiences shaping how non-Muslim visitors came to appreciate the site, namely: curiosity in learning more about Islam and its heritage sites; viewing icons of religious difference and taking photos; and personal interaction. Such experiences were explicitly secular and corresponded predominantly to the divergence paradigm of religious tourism. Important issues to be considered for the development and growth of non-Muslim mosque tourism are discussed. Finally, the paper indicates avenues for future research.
\end{abstract}

Key words: mosques; Egypt; non-Muslim visitors; motivations; experiences; religious tourism.

\title{
Introduction
}

The present study is situated within the broad realms of religious tourism and pilgrimages, within an Islamic context. The link between religion and tourism has caught the attention of tourism academics, media and tourism promoters in recent years (Bader, 2012; Hall, 2006; Margry, 2008; Kaelber, 2006; Kamil, 2000; Orekat, 2016; Vukonic, 2002). This interest has largely been spurred by the economic potential of religious travel and the social-cultural and physical impacts of tourism development at sacred sites (Rojo, 2007; Orekat, 2016). Religious travel has played a significant part in improving the economy of certain regions and cities, such as Haifa and Jerusalem in Israel (Collins-Kreiner, 2010a; Collins-Kreiner, Gatrell, 2006), the Vatican City in Italy (Marine-Roig, 2015), Santiago de Compostela in Spain (Santos, 2002) Vrindavan in India (Shinde, Rizello, 2014), Loudres in France (Eade, 1992), and Medju-

\footnotetext{
Tourism College, Institute for Tourism Studies, Colina de Mong-Há, Macao, China

Correspondent author: ahmed@ift.edu.mo
} 
gorje in Bosnia-Herzegovina (Katić, 2014), to name but a few. According to the United Nations World Tourism Organization (UNWTO), an estimated 300-330 million people visit major religious sites around the world every year (UNWTO, 2014). As such, a number of scholars have tried to define and highlight the differences and similarities between a secular, a pilgrim and a religious visitor (i.e. Bond, 2013; Badone, Roseman, 2004; Cohen, 1992; Di Giovine, 2011; Eade, 1992; Graburn, 1989; Hyde, Harman, 2011; Margry, 2008; Ozkan, 2013).

Religious tourism may be perceived as the ways in which sacred places relate to visitors' expectations, needs, wants and interests. One definition is provided by Vukonic (1996) who argued that the religious tourist is a person who carries out his/her journey for pure religious motives (i.e. religiosity is the independent variable and no other motivations are involved) and who requires that particular religious sites, events and buildings be included in the "framework of a touristic itinerary" (p. 75). Other studies (i.e. Bond, 2013; Gerrard, 2010; Kaelber, 2006; MacCannell, 1999; Orekat, 2016; Ozkan, 2013; Shinde, Rizello, 2014) have examined visitors' motivations and experiences of the religious tourism destination and found that religious tourism experiences frequently co-exist with secular (non-religious) experiences such as getting away from mundane environments at home, relaxing, socializing and bonding with friends and family or exploring and learning about the sacred sites. While there is at present no uniform definition of religious tourism, the most widely accepted academic definitions of religious tourism include that form of tourism whose participants aim to fulfill cultural, religious, spiritual, educational and recreational needs. It involves attending religious events, festivals, conventions and conferences, visiting international, national or regional pilgrimage sites, and all other religiously-oriented meetings that necessitate travel away from the home environment (Collins-Kreiner, 201ob; Shackley, 2001, 2002; Shinde, Rizello, 2014).

Tourism or trips with religious purpose have a particular significance in many tourist destinations. On one hand, mainly due to intrinsic motives that spark these journeys, they have special importance for the travelers who make them. On the other hand, these practices bring a variety of benefits to the local communities in which are practiced. However, a change over time can be observed from trips with a single motive - purely religious pilgrimages, to trips with multiple motives. Few travelers now reveal a singular motive for their journeys, including those who carry out religious pilgrimages (Marine-Roig, 2015; Shackley, 2001). In addition, more and more guardians and representatives of sacred sites have to confront the challenges created by the simultaneous management of visitors with complex and multifarious motivations (religious, spiritual and otherwise) who visit their religious sites (Rodrigues, McIntosh, 2014; Wong, et al., 2013).

Previous research has considered tourist experiences at sacred sites of various religions. In particular, several previous studies have been conducted with visitors who travel to established Christian sacred sites (i.e. Collins-Kreiner, Kliot, 200o; Eade, 1992; Marine-Roig, 2015; Rodrigues, McIntosh, 2014; Rojo, 2007; Shackley, 1998; Santos, 2002). Through these studies, a typology has been constructed of secular and religious tourists' characteristics and behaviors; for example, drawing up a taxonomy of spiritual tourist experiences, identifying differences and similarities between secular and religious travelers, or exploring perceptions and attitudes of local residents towards the physical, socio-cultural and economic impacts of religious tourism development. Other studies have yielded important insights into religious and secular visitors' experiences of Buddhist (i.e. Wong, 2016; Wong, et al., 2013), Ba'hai (i.e. Collins-Kreiner, Gatrell, 2006), Hindu (i.e. Shinde, Rizello, 2014) and Jewish holy sites (i.e. Collins-Kreiner, 2010a), and the potential positive and negative impacts of tourism on such sites (i.e. Suntikul, 2008). Much of the previous literature has focused on visitors in the context of 
established Buddhist, Ba'hai, Hindu, Christian, and Jewish sacred sites (Collins-Kreiner, Kliot, 2000, 2010a; Collins-Kreiner, Gatrell, 2006; Eade, 1992; Katić, 2014; Marine-Roig, 2015; Rodrigues, McIntosh, 2014; Santos, 2002; Shinde, Rizello, 2014; Shuo, et al., 2009; Suntikul, 2008; Wong, et al., 2013). This burgeoning research interest in religions other than Islam highlights a substantial gap in the literature.

Although several research works have been conducted on Muslim visitors' tourism to Islamic holy sites, previous literature is surprisingly silent on the topic of non-Muslim visitors (also known as secular or Western visitors) engaging in tourism at Islamic sites. Many of the existing studies on Islamic tourism (Battour, Ismail, 2016; Bhuiyan, et al., 2011; Gunlu, Okumus, 2010; Haq, Wong, 2013; Raj, Bozonelos, 2015; Shafaei, Mohamed, 2015; Stephenson, 2014a, 2014b; Zamani-Farahania, Eidb, 2016) have focused largely on Muslim visitors' motivations and experiences when visiting Muslim cultural and holy sites (i.e. shrines and mosques), and as such, lack consideration of the perspectives of non-Muslim visitors. Besides, non-academic sources, such as newspaper and online articles (i.e. Kamil, 20oo; Neumann, 2014; Temporal, 2011), tend to be anecdotal; either they emphasize how to brand Islamic tourism in Europe and North America or they offer advice on how Islamic tourism developments/operations in Muslim countries can cater to Western (non-Muslim) tourists. Also, in some Islamic countries, including Jordan and Egypt, Islamic sites are blocked from view or intentionally not developed for tourists because Christian sites are considered more familiar and thus more attractive to Western visitors. Following this logic, it is not surprising that little research exists on non-western visitors to Islamic sites (Addison, 2004; Orekat, 2016).

In a review of research on tourism and Islam, Jafari and Scott (2014) particularly identified development of tourism in the Islamic world that caters to non-Muslim (Western) visitors as an area that needs to be further researched. They argued that a sizeable literature falls into three categories: overlooking religion, equating religion as culture, or concentrating on religion as essential. The first two of these categories downplay the role of religion in the Muslim world, in effect overlooking or apologizing for religion. The third type, in contrast, argues that the locals and their religious practices need to be protected from the influences of non-Muslim tourists. The present study is none of these three types. Rather the present study fills a gap by showing through a case study how Muslim religious practices can be made accessible to non-Muslims in a non-apologetic and non-threatening way. Moreover, rather than ignoring the religious aspects, this study explores from Westerners' viewpoints how and why visits to a Muslim country should include at least the option of a mosque visit to understand more about the religious beliefs that strongly shape the country.

The main contribution of the present study lies in explaining the central motivations which cause non-Muslim visitors to visit mosques, which are in turn closely linked to the experiences these visitors have in relation to the mosque decorations, symbols and activities. More particularly, this study explores non-Muslim international visitors' motivations and experiences when visiting the Al- Azhar Mosque, one of Cairo's most important mosques. To understand the Al-Azhar Mosque case, this paper examines the unique nature of pilgrimage-tourism and the religious, historical and cultural significance of the mosque. The following section details the relevant literature related to different types of visitors at religious sites. This is followed by details about the methodology utilized, background information of the case study site, visitors' demographics and a discussion of the resulting themes from the study. This paper concludes with specific insights regarding the development of mosque-visiting. 


\section{Visitor taxonomy at religious sites}

Religious tourism is a complex phenomenon, involving a broad range of visitors seeking different experiences for widely variant motives. For a number of destinations worldwide, a significant portion of the inbound international tourists are travelling for religious motives. Examples of such destinations include Egypt (Shackley, 1998), Jordan (Bader, 2012; Orekat, 2016); Israel (Collins-Kreiner, Kliot, 200o; Collins-Kreiner, Gatrell, 2006; Collins-Kreiner, 2010 a,b,c), Saudi Arabia (Raj, Bozonelos, 2015), India (Shinde, Rizello, 2014), Italy (Santos, 2002) and France (Eade, 1992). However, while religious tourism is most commonly associated with the pursuit of religious fulfillment or spirituality, it is more complex than this (Badone, Roseman, 2004; Rojo, 2007; Vukonic, 1996). Many additional secular (non-religious) tourists visit religious sites and buildings because they are interested in either the relaxed lifestyle, friendly people, peaceful and beautiful landscape or the cultural and historical value of those sites rather than in their sacred or spiritual value (Hall, 2006; Suntikul, 2008).

By reviewing the similarities and differences between pilgrimage and tourism, the complexities of tourists' motivations and experiences can be revealed. While some tourism academics (i.e. Bond, 2013; Liebersohn, 1996; Ozkan, 2013) define pilgrimage as a form of tourism, others (i.e. Cohen, 1979; De Sousa, 1993; Shackley, 2001) consider pilgrimage and tourism different forms of travel. This has created vagueness concerning who could be described as a secular visitor, a pilgrim or a religious visitor. Visiting international, national or regional sacred sites, and even attending religious festivals and events, are not limited to sacred visitors; rather, the presence of secular visitors at religious sites is also common (Collins-Kreiner, Gatrell, 2006; Olsen, 2013). Indeed, it has been debated that religious sites and events draw more secular visitors than their pious counterparts (Collins-Kreiner, Gatrell, 2006; Shinde, Rizello, 2014). Swarbrooke and Horner (1999) maintain that churches and cathedrals are becoming significant sites even for non-religious visitors.

Hence, the tourism literature has put forward the significance of understanding the different types of visitors at religious sites. This knowledge will help to clarify the potential impacts that visitors have on such sites and assist tourism site organizers and marketers to arrange and market their tours differently for different types of visitors. Secular, religious and spiritual elements constitute the reasons that motivate both religious and secular visitors to visit a specific destination (Di Giovine, 2011; Santos, 2003). However, religious and non-religious visitors are difficult to clearly differentiate (Olsen, 2013). Tourism research which has explored religious and secular visitors' motives and experiences suggests two main paradigms, namely, divergence and convergence.

\section{Convergence paradigms}

Scholars of the convergence paradigms (i.e. Bond, 2013; Di Giovine, 2011; Gerrard, 2010; Kaelber, 2006; MacCannell, 1999; Ozkan, 2013; Rinschede, 1992; Shinde, Rizello, 2014) have tried to view tourists and pilgrims as two roles performed simultaneously or at different times by the same visitor to a sacred site. Such scholars perceive pilgrims as visitors with secular and/or religious motives. They argue that while some pilgrims are driven by religious motives (for example, to experience places where sacred individuals had walked, to understand one's spiritual being, or to seek to strengthen one's faith) others are inspired by non-religious motives (for example, curiosity, a desire for adventure, exploration of something different, and cultural knowledge and enrichment). A number of scholars (Graburn, 1989; Hyde, Harman, 2011; Mar- 
gry, 2008) described tourism as a sacred journey in which tourists leave their mundane environments to experience the non-ordinary sites with the intention of acquiring spiritual or physical benefit or transformation. Hence, from this point of view, both religious and secular tourists are searching for non-ordinary sites to satisfy their psychological needs and wants through a transformative experience. Along the same lines, MacCannell (1973, p. 593) perceives tourism as 'the pilgrimage of modern man' where he can flee from the modern world and let himself to be exposed to an authentic experience (MacCannell, 1999). Therefore, MacCannell advocates viewing tourism as a modern substitute for religion, since pilgrims and tourists are searching for sites of social, religious, cultural, and historical significance. Later, Badone and Roseman (2004) concurred, arguing that the pilgrims and tourists have a common quest for authenticity and meaningful experiences, and accordingly the differences between pilgrims and tourists appear "no longer tenable in the shifting world of postmodern travel" (p. 2). Similarly, Turner and Turner (1978), recognizing that the experiences of the pilgrim often include non-religious activities, suggested that "a tourist is half a pilgrim, if a pilgrim is half a tourist" (p. 20). Thus, Vukonic (2002) points out that the similarities between the tourist and the pilgrim blur the dichotomies between pilgrimage and tourism and consequently restrict the scope of comparative analyses.

It has been argued that the distinction between pilgrims and tourists is so blurred that it could be considered non-existent (Kaelber, 2006; Liebersohn, 1996; Rojo, 2007). Tourists who seek experiences to satisfy their motives to learn and gain knowledge share similar interests and experiences with pilgrims, since both of them are searching for physical benefit and transformative experience and can attain self-satisfaction. Accordingly, Kaelber (2006) and Rojo (2007) propose that educational and cultural tourists are pilgrims as well. In the same vein, Nolan and Nolan (1992) emphasized that visitors, who may belong to other religions, sects or denominations not directly associated with the holy site, usually visit not entirely with a religious motive, but also for educational and cultural purposes or out of mere curiosity. Other such visits are linked to holiday making or to trips carried out for social purposes, some of which have nothing to do with religion directly (Poria, et al., 2003; Shinde, Rizello, 2014).

In fact, pilgrimage behavior has been observed to places not associated with any established religion. Badone and Roseman (2004) went further to claim that football fans, such as Liverpool fans, could be considered pilgrims since they perceive their club as their sacred site or religion. Other researchers (Alderman, 2002; Margry, 2008; Reader, Walter, 1993) have explored other forms of pilgrims, such as those who visit homes and graves of celebrities and behave in a similar way to those who carry out religious practices and rituals at churches and temples. In this sense, one may argue that pilgrimage is accelerating the convergence of the secular and sacred site, and narrowing the differences between secular and religiously motivated visitors, both of which could be described as pilgrims.

Nonetheless, perceiving a pilgrimage experience as one that has effectively forged a link with cultural and educational or other secular motives may be too simplistic. It does not provide an in-depth account of the spiritual and religious factors that pilgrimage has on visitors' experiences. Bond (2013) explored pilgrimage and religious tourism experiences at different British Cathedrals. Based on the data he collected, he indicated that converging paradigms do not explore in-depth visitors' motives, experiences, needs, wants, and personal goals, and they do not differentiate pilgrimage from other types of tourism such as wine tourism or even sex tourism. Moreover, visitors who are driven by "personal growth," "New Age spiritual travel," "non-traditional spiritual practices," and "the search for the miraculous" may be considered as spiritual tourists without being pilgrims, since pilgrimage commonly refers to a set of 
religious practices and rites that exist in a sacred space which distinguish the experience from the ordinary and enable a visitor "to access God or the divine figure in their cosmology" (Collins-Kreiner, Gatrell, 2006, p. 33). Since convergence paradigms fail to adequately explain the variety of motives and experiences of such visitors, let us now turn to the other major approach - the divergence paradigms.

\section{Divergence Paradigms}

The main tenant of divergence paradigms is that pilgrims and tourists are, in fact, not alike in their motives and experiences. Cohen (1979), the first to provide detailed examination of the concept of dichotomy between pigrims and tourists, maintains that tourists who engage in the "existential mode" are akin to pilgrims, while those who engage in the "recreational mode" are similar to tourists. From Cohen's (1979) point of view, both types of tourists are regarded as having particular characteristics. While pilgrims seek deep meaning and are "committed to elective spiritual center," meaning their motives are purely spiritual or religious, tourists search for entertainment and leisure that accentuate the restorative power of the journey (Cohen, 1979, p. 190). Later, Cohen's (1992) study explored tourists' and pilgrims' activities at four types of Thai Buddhist shrines, concluding that tourism and pilgrimage differ in terms of the aim of the journey undertaken:

Pilgrimage and tourism differ in terms of the direction of the journey undertaken... [T] he pilgrim, and the 'pilgrim-tourist' peregrinate toward their sociocultural center, while the traveler and the 'traveler-tourist' move in the opposite direction (Cohen, 1992, p. 37).

Other scholars continued to explore the dichotomy of the two types. In the case of travelers to the Holy Land (Israel), Collins-Kreiner and Kliot (2000) noticed a number of motives and behavior patterns that were strongly tied to religion, whether these motives were to experience the sacred places where Jesus walked, to understand one's spiritual being, or to seek to strengthen one's faith. Later, Collins-Kreiner and Gartell (2006) also found that in the Bahai Gardens in Haifa (Israel) pilgrims and secular visitors had different experiences and behavior patterns during the tour and while they were on site. There was not as much blurring between pilgrimage- and tourism-like behavior as was noticed in other case studies. For example, Bahai pilgrims had clearer methods of practicing their religious faith, while their secular counterparts were not committed to a particular method. For example, Collins-Kreiner and Gatrell (2006) found that Bahai pilgrims who visited the Bahai Gardens in Haifa (Israel) practiced certain activities related to Bahai faith, while secular visitors were interested in the aesthetic features of the gardens. Later, Collins-Kreiner (2010) called for research paradigm division of pilgrims and non-pilgrim tourists at religious heritage sites.

Following the same divergence angle, Shackley's research also (2001, 2002) divided visitors into two segments - visitors whose primary purpose to visit was religious versus those whose motives to visit were based on architectural, historic and cultural interests. The findings of these scholars (Collins-Kreiner, Gatrell, 2006; Shackley, 2001, 2002) are interesting since they are in contrast with Shuo, Ryan and Liu's (2009) findings where the same visitor shows strong religious motives and experiences at the Da-Lin Temple in Taiwan (for example, being close to God, seeking to experience a holy atmosphere and strengthen one's beliefs) alongside secular ones (for example, curiosity, leisure, cultural and educational). In this sense, the same religious visitor is not entirely immune from secular motives and can shift easily from the role of devoted pilgrim to tourist and vice-versa. 
Scholars have also attempted to explore the differences between pilgrims and tourists by employing visitor typology methods. For example, Smith (1992) distinguishes between pilgrims and tourists as a continuum, with the secular tourist representing one pole and the pious pilgrim the other pole and between the two axes lie an array of secular-sacred combinations. She examined the different experiences of the two segments and concluded that tourists and pilgrims both have different motivations. However, this visitor typology method also paved the way for her to identify a number of shared motives and experiences among the two groups such as spiritual experiences and the search for authenticity. The Santos (2003) tourist typology, influenced by Smith's continuum model, identified religion and tourism as opposite end points on a continuum of travel, with the seemingly sacred-secular scale between the two based on the tourists' perceptions of the significance of the religious sites, their religious background and the experiences they anticipated having at those sites. Interestingly, Santos' model did not show a vast difference between the religious and secular as a number of common motives and experiences are positioned in the middle ground between pilgrimage and tourism as suggested by Smith (1992). Instead, Santos (2003) considers religious travel as a much broader phenomenon encompassing all types of travel "(voluntary, temporary and unpaid) that is motivated by religion in combination with other kinds of motivation, and which has as its destination a religious site (of local, regional, national or international status), but for which the journey itself is not a religious practice" (p. 27).

Convergence scholars argue that religious motives and experiences overlap with secular ones. This contradicts divergence researchers who consider pilgrims and tourists as different types of visitors: the former comes with religious motives and the later with secular motives. In the case of non-Muslim visitors at the Al-Azhar Mosque, the relevance of religious and secular motives, as well as the related behaviors while visiting the mosque, should be explored.

\section{Research on non-Muslim visitors}

Previous research on non-Muslim visitors to Islamic holy sites is rare. In some cases, research has shown that Islamic sites may be downplayed in tourist promotions while focus is given to non-religious experiences or holy sites of religions thought to be more familiar or attractive to Western tourists. For example, Addison (2004) describes how in Jordan, Islamic sites are often left crumbling and all but hidden from tourists while sites linked to Christian heritage are restored and given clear signage. If Islamic holy sites are not being actively promoted to non-Muslim tourists, it is not surprising that research on those who do visit is scarce. Jafari and Scott (2014) particularly identified tourism in the Islamic world which caters to non-Mus$\lim$ (Western) visitors as an area in need of further research. They explained that to date, three types of studies exist on tourism in the Muslim world. The first two types either ignore religion or equate religion with culture, both of which downplay the central role of religion in Islamic countries. The third type acknowledges the importance of Islam in these countries, but focuses on the potentially negative impacts of non-Muslim visitors to the Muslim residents. Thus the interactions of non-Muslim visitors with Islam and its holy sites are in need of further study. In one study by Kuo (2007), the reasons Western visitors came to a mosque in Dubai were asked through closed question questionnaires. This study found that wanting to know about Islam, wanting to know about the local culture, and wanting to see the inside of a mosque were identified as the main motivations for joining a guided talk in the mosque. These motivations were all linked to curiosity and a desire to learn. However, as Kuo did not 
use a qualitative approach, some motivations for visiting may not have been uncovered, and the resulting experiences in the mosque were also not considered.

Thus the current study addresses a number of gaps in previous literature by exploring through a case study of Al-Azhar Mosque in Egypt how Muslim religious practices are made accessible to non-Muslim visitors. This study uses the qualitative approach to explore the relationship between religious and secular motives for non-Muslim visitors to the mosque, and examines in more detail how and why Westerners choose to engage with the mosque and religious beliefs that strongly shape the country. This paper now shifts to presenting the methodology that was employed to carry out the study.

\section{Methodology}

This study is anchored within qualitative research methods since they provide complex data about the individual visitor experience (Blaxter, Tight, 1996; McIntosh, 1998). A case study approach was adopted in this study to provide detailed insights into non-Muslim visitors' motivations and experiences at the Al-Azhar Mosque. Case studies are relevant to the research project when the researcher is interested in "how," "what" and "why" questions (Ellinger, et al., 2005 , p. 4). A case study method enables the researcher to understand a complex event, experience or practice. Choosing a limited number of sites is not only cost-effective but provides limits to the research context by concentrating on a particular site, population, phenomenon or characteristics (Decrop, 1999). Yet, as Yin (2003) notes, one of the disadvantages of the case study approach is that findings are specific and may not be relevant or applicable to other settings.

The Al-Azhar Mosque was purposefully selected for this study because the lead author is able to provide an insider perspective of the mosque. The lead author is an Egyptian who was a long-term resident of Cairo. As an insider, the lead author is familiar with the historical development and significance of the mosque and has experienced the site from a variety of perspectives-researcher, religious tourism consumer, resident, and passerby. No matter how much knowledge he had about the site, the lead author maintained a certain "scientific detachment" (Babbie, 2004, p. 279) in his role as a researcher and relied only on the perspectives and voices of the participants (Corbetta, 2003; Patton, 2002). He was constantly aware of and attentive to his own culture, history, social, political and religious origins as well as his differences from those he talked to during the fieldwork. Hence, during every interview he aimed to remove himself from his own cultural and social context and endeavored to open himself to the visitor's world and his/her own narrative of experience (Rubin, Rubin, 2005).

This study adopted face to face semi-structured interviews since they are very effective in eliciting narrative (Patton, 2002); they also let the research process be adapted to the interviewees, facilitating probing for answers, clarifying statements, and exploring new ideas and views (Babbie, 2004; Polkinghorne, 2005; Rubin, Rubin, 2005). Permission to interview non-Muslim visitors and sheikhs was obtained prior to the commencement of the fieldwork phase of the research (Decrop, 1999). A detailed copy of the research proposal was emailed to the mosque's management committee to facilitate approval being granted at the site. The lead author then approached management by telephone and emails to finalize the fieldwork periods. The Islamic identity of the lead author certainly contributed to facilitating rapport and creating trust with management, allowing him to be welcomed by a number of senior sheikhs who led the 
guided tours, lectures, and classes for international visitors. Adequate lists and consequently sample frames for European and North American visitors who booked their mosque tours were made available for the researcher; therefore these lists were considered to be the most effective technique to obtain a purposive sample of non-Muslim visitors.

The data came from 26 non-Muslim visitors from three guided tours and they were interviewed on the completion of their tours. An additional four interviews were conducted with the sheikhs who conducted the guided tours. This sample size was not considered a limitation as sample sizes of 20-25 interviewees are generally considered adequate for exploratory studies of this nature (McIntosh, Prentice, 1999; McIntosh, Siggs, 2005; Creswell, 2009). Furthermore, sample size of the study was determined when the point of data saturation was attained; that is when the same information was being reported without anything new being added (Babbie, 2004; Patton, 2002).

All interviews and site visits took place over a four-month period in the summer of 2015 . Only visitors aged 18 years or over were interviewed. The researcher also excluded participants who were not fluent in either English or Arabic, as these were the two languages in which the interviewer was fluent. Non-Muslim visitors who were willing to participate were offered a small incentive, such as a cold drink or a cup of tea or coffee, to encourage and thank them for their time. This was offered before they agreed to take part in the research. The interviews with visitors ranged from 40 to 50 minutes while interviews with the sheikhs lasted approximately 60 minutes. Standardized open ended questions were utilized to elicit as accurately as possible visitors' motives and experiences, as expressed in their own words and in relation to pertinent issues they raised. For example, visitors were asked to describe what they had experienced, why an experience of the mosque had been important to them, and whether they had learnt anything new about Islam from their visit. With regard to the interviews with the sheikhs, the questions were framed so as to find out about their perceptions of tour groups from different countries, the content of their tours and the activities in the mosque. The interviews were tape-recorded and transcribed. As the lead author is bilingual in English and Arabic, the interview transcripts were translated into English when needed. The authors followed Behling and Law's (200o) technique of "Translation/Back-Translation" where the lead author met with a bilingual specialist at Cairo University and they examined the language of the Arabic transcripts and documents until they reached an agreement.

The interviews were supplemented with participant observation work since this approach can extend the researcher's perspective in field research (Babbie, 2004). As participant observer, the lead author - at numerous and different times - participated in the tours as a researcher and tourist, experienced the mosque architecture and decor, and visited the adjacent green landscaped gardens of Al-Azhar Park. As the author was a participant observer, the study includes empirical observations concerning the observed practices of visitors and the material landscape.

All interviews, field notes, observational data and documents were analyzed using qualitative content analysis to elicit common themes and sub themes relating to the nature of the mosque visit. By looking for key terms and phrases, lengthy interviews with participants, were reduced to manageable blocks of text, from which relevant quotes have been selected (Decrop, 1999). Moreover, observational data and field notes were also triangulated with interview responses which allowed the researchers to move beyond a single view of the mosque experience. Before presenting the emergent themes from the study, the following section will provide a broad overview of the case study site since this overview provides an important context for understanding the findings. 


\section{Background and context of the Al-Azhar Mosque}

The study site is located in Egypt's capital and largest city, Cairo, with a population of roughly 17 million. The city occupies roughly 453 square kilometers on both banks of the Nile River. Its architecture, a combination of modern and traditional forms, reflects its long and rich history. Cairo is known as "the City of 1,0oo Minarets" since mosques spread across all city neighborhoods. It is also renowned as the "Hollywood" of the Middle East because of its movie industry, popular Arab music and singers and its International Film Festival. Historically, the city has been regarded as a more secular city in comparison to other Egyptian cities. Indeed, Cairo is often understood by its residents to be a multi-cultural city with its intellectual and religious qualities seldom associated with contemporary religious conflict. The city abounds in Pharaonic, Coptic, Islamic and Jewish monuments and heritage sites. There are 560 Islamic monuments in Cairo. One of the most important is Al-Azhar Mosque (AlSayyad, 2013; Behrens-Abouseif, 1989).

The Al-Azhar mosque, a one-thousand-year-old institution, is part university (including modern faculties) and part center of Islamic scholarship. It was founded in the oth century (973 AD), shortly after the founding of Cairo itself. Situated in the heart of Cairo, the mosque's history is rooted in the city's past. The mosque is one of the most important mosques in Egypt and the most renowned mosque in the Islamic and Arab countries (AlSayyad, 2013). The intention behind building the mosque was to make it the official mosque of Cairo. Fifteen years later, in $988 \mathrm{AD}$, the school of theology (madrassa), known later as Al-Azhar University, was established and has been linked to the mosque. The university is located at the mosque's northeast corner and can be accessed from within the mosque. The mosque and university are named in honor of Fatima al-Zahra, the daughter of Prophet Muhammad. The word Al-Azhar is an epithet meaning the flourishing or the blossoming (Behrens-Abouseif, 1989). Al-Azhar University is one of the oldest universities in the world, and has taught Islamic law, grammar, rhetoric, theology and Arabic for more than 1,0oo years. The university now stretches well beyond its original boundaries, and many buildings have been added throughout its history, right down to the 2oth century. Both the mosque and the university are part of the Historic Cairo UNESCO World Heritage Site (AlSayyad, 2013; State Information Service, 2016).

Because of its significance, the mosque of Al-Azhar has undergone a series of restorations and expansions throughout its history. The mosque itself is spacious with a large central courtyard and spectacular architectural details. Currently, all eras and styles of Cairo's history are represented in its architecture (State Information Service, 2016). The main entrance of the mosque is through the 15 th-century Barber's Gate, where students traditionally had their heads shaved. This leads the visitor into a large open air courtyard (sahn), which dates from the 1oth century and is overlooked by three minarets (Figure 1). From the courtyard's white facade, the visitor can view the residential quarters of the old university, which are not open to visitors. The visitor would then walk into the prayer hall (qibla) which is warmly carpeted with a thick red rug and supported by alabaster pillars (Figure 2). The mosque has five minarets with small balconies and intricately carved columns. The roof and minarets offer visitors panoramic views of the city and the surroundings. Visitors may also encounter a number of students relaxing in the mosque, reading or chatting with friends, and sometimes they offer guiding service.

The mosque is open for visitors Monday - Thursday $9 \mathrm{am}-6 \mathrm{pm}$, and Friday $3 \mathrm{pm}-6 \mathrm{pm}$; and opens for prayer daily $9 \mathrm{am}-9 \mathrm{pm}$. Visitors are required to dress modestly upon visiting the mosque. For example, women should cover their head and arms, and not wear short skirts; men 
should not wear shorts. Scarves and burkas are available at the entrance for women, and both men and women need to remove their shoes at the entrance.

Although the mosque offers free admission to international and domestic visitors, it charges fees for roughly two hour long guided lecture tours. Independent visitors are required to book the tour 24 hours in advance of their visit. Travel agents are required to book their groups at least 48 hours before the visit. All the respondents in this study booked their visit using tour operators. The mosque tours operate daily, year round, and they are relaxed, enlightening, and interactive. They are offered by various bilingual sheikhs (also known as faith guides) who are serving in instructor positions at the university. The mosque has different sheikhs who speak Arabic, English, Spanish, French, German and Italian, and their role most closely resembles that of tour guides. Tours are not conducted during the prayer time, which takes place five times for about half an hour per time.

A typical visit to the mosque consists of the following major elements. First, a short introductory talk is given in the prayer hall on the Sunni Islamic faith. Next, the faith guide takes visitors on a walking tour, explaining the history of Al-Azhar Mosque and university. Then visitors observe one of the daily or special prayer services, and lastly, the tour ends with a roughly 40 minute question and answer period and discussion session. Faith guides vary in their methods of presentation, but most of them entertain questions throughout the tour. A complimentary snack of dates is usually provided for visitors at the end of the tour. The mosque also organizes tours for VIPs, journalists and international scholars.

\section{Study findings}

\section{Visitors' demographics}

The respondents were all international visitors who came from Western markets: United Kingdom, France, Netherlands, USA, Sweden, Belgium and Germany. They were representative of the general profile of Western visitors to Egypt in terms of travel style, age, gender and nationality (The Egyptian Tourism Authority, 2010/2015). The under-representation of North American visitors and the dominance of British, German, Italian and French respondents might be partially explained by the geographical proximity of these markets and the vigorous marketing campaign of the Pharaonic and Islamic heritage sites in these particular destinations in the aftermath of Egypt's 2011 Revolution (Al-Shuwekhi, 2014; The Egyptian Tourism Authority, 2012). All the interview respondents travelled with an organized tour company. Of the 26 visitor respondents interviewed, the majority were between 35 and 55 years of age. The gender ratio amongst respondents was nearly even (14 males and 12 females). Educational, health and managerial professionals were highly represented amongst respondents, with 23 of them stating various managerial or professional careers. Most of the respondents (24 of the 26) indicated that their annual income is less than $\$ \mathrm{US} 60,000$. One possible explanation for the dominance of professional and managerial occupations of the respondents is that the cities of Cairo and Luxor tend to attract more high-yield heritage visitors who stay longer and spend more than other tourists (The Egyptian Ministry of Tourism, 2012). Research on visitors to religious heritage sites (Bond, 2013; Orekat, 2016; Rodrigues, McIntosh, 2014) has also found that visitors to such sites are generally well educated, older, employed in professional occupations and spend more money.

A distinctive finding of this research was that all of the interviewed respondents identified themselves as Christians, but they were not currently practicing their faith. Those who 
are actively practicing a religion may be more inclined to visit religious sites of their own religion while those who are not practicing their faith, that is those with merely a cultural background of a certain religion, may be more open to visiting religious sites of other faiths. It should be noted though that all the respondents confirmed that they visited the site for curiosity and knowledge purposes (for example, gaining more knowledge about Islam and learning about the history and culture of the site) and none came for religious purposes. The respondents correspond closely to Shackley's (2001) and Collins-Kreiner and Gatrell's (2006) studies where they identified two groups of visitors at religious sites: those who visit a sacred site for a pure religious purpose such as pilgrims and those visiting it for educational purposes or out of mere curiosity. All of the respondents were married and they all joined the tours with a partner, friends, and relatives, such as grandparents and cousins. In fact, Rodrigues and McIntosh's (2014) study on a Catholic monastery in New Zealand and Bond's study (2013) on English Cathedrals showed similar findings, where most participants visited the sites as part of a social group and found safety and comfort in groups.

\section{Visitors' motives and experiences at the mosque}

Most of the respondents (19 out of the 26) learned of the existence of the mosque after they arrived in Egypt through tour agency brochures or the Egypt Tourism Authority's website, while the rest heard of the mosque from previous international visitors. Data obtained from the respondents revealed three distinct themes of commonly reported motives and experiences for visiting the site, which are explained below with respondents' quotes to illustrate the themes. These themes include the following: "curiosity and learning more about Islam and its heritage sites," "taking photos and gazing on icons of religious difference," and "personal interaction." Some of the respondents described multiple motives for visiting the site, and as such, the three themes are not mutually exclusive. It is important also to note that respondents' motive to learn was not from a position of ignorance about Islam; rather their exposure to Islam already had made them eager to learn more about the religion, as the following quotation attests: “That's why I wanted to come here, because I want to expand my knowledge about Islam. I can't imagine a better place to come ... I've read about it, I've learned about it and I've been bombarded with images of Islam by the media" (German respondent).

\section{Curiosity and learning more about Islam and its heritage sites}

A major theme which emerged from visiting the mosque was that of "curiosity and desiring to learn more about Islam and its heritage sites." Curiosity and wanting to learn were reported as non-religious motives for visiting the site. A sense of "I want to see the oldest mosque in Cairo" (Belgian respondent) and "Visiting this site was on our Cairo sightseeing list because we were curious to see the 1000 year old mosque" (UK respondent) initiated the selection of the mosque. In Rodrigues and McIntosh's (2014) research, curiosity was similarly a non-religious motive for visiting a monastery.

Visitors' general responses also reflected their educational motives for visiting. Learning was an explicit and predominant motivation for the visit. Two respondents voiced the views of the majority of interviewees, "We very much wanted to visit Al-Azhar, which I knew was a center of Islamic learning for centuries. I want to see the building and learn about its history in more detail" (Italian respondent); "This visit gave us the opportunity to learn about one of the oldest mosques in the world and see what the mosque has to offer ... It's my curiosi- 
ty to try to experience and learn about Islam and its heritage sites in other parts of the world, and for me Al-Azhar is very stimulating" (UK respondent). Furthermore, several respondents joined the guided tour with a desire to learn more about particular topics or issues based on something they had seen, heard or read about. "I watched a TV documentary on the fighting between Shia and Sunni Muslims in Iraq and I was just curious to know more about these two sects from the sheikhs especially that the mosque represents the Sunni group" (French respondent). Likewise, Kuo (2007) also found curiosity and a desire to learn about Islam and the mosque as the main motives for mosque visitors to Dubai.

The respondents' learning experiences followed out of the motivations mentioned above. In the present study, 21 out of 26 interviewed stated that they had "learned something new" about the site and Islam from their visit. Visiting the mosque also affected them positively. When asked "What did you like most about your visit to the mosque today?" The words of two interviewees voiced the opinions of many respondents: "It was an easy, pleasant educational tour where we learned many new things about Islam and the role of Al-Azhar in the Muslim world. It's really [the tour] also made me think more about what I don't know about Islam. It allows me to go beyond the stereotypes built through our American media back home" (USA respondent); "It's a great moment of enlightenment. I never realized that Sharia deals with everything politics, economics, business even mental health and sexuality. That's why in Islam there can be no separation between church and state" (Dutch respondent). Terms such as "made me think more" and "allows me to go beyond the stereotypes" show that the visit expanded this secular visitor's understanding of Islam. Previous research likewise shows that the desire to learn about other religions was a popular reason for the visit, though the extent to which visitors actually learn about the religion varies greatly with the length and types of tour (Bond, 2013; Graburn, 1989; Olsen, 2013). There is also some evidence to suggest that secular visitors who visit sacred sites to experience the religions or cultural of others develop a compassionate understanding of other people and their religions (Wong, et al., 2013).

Furthermore, the findings suggest that mosques should not primarily be considered places where only Muslims attend to perform the salat (prayer) and recite the Quran. They could instead be redefined as sites that provide learning experiences to non-Muslim or secular visitors (Figure 3). Two faith guides lent support to this learning phenomenon at mosques: "Mosques have been centers for ilm (learning) since the prophet's time. Our job is not only to take the foreign tourists around the mosque, but to educate them, to teach them about the site and Islam and we try to simplify the explanation of Islam for better understanding" (Sh. 101). Another guide concurred: "The mosque served not only as place for Muslims to worship but also as a school ... one trick I use to teach non-Muslim tourists is trying to find something that is going to be familiar to them. Something they can relate to. I try to talk about the Prophet and Jesus. Then they become interested and ask many questions" (Sh. 103). These comments also, while requiring further substantiation, potentially confirm the importance of the religious or spiritual/faith guides at sacred sites. Such guides often function as site educators or community leaders, and play a vital role in forming the image of the site since they have direct contact with visitors (Collins-Kreiner, Kliot, 2000; Rodrigues, McIntosh, 2014; Wong, et al., 2013).

\section{Taking photos and gazing on icons of religious difference}

Although learning about the site and Islam was important, several respondents indicated the desire to "gaze on different signs and taking photos" (UK respondent). This is consistent with the nature of tourism consumption described elsewhere (Urry, 2001). Again, respond- 
ents' experiences in these regards are more akin to secular practice than religious tourism. When respondents were asked to describe how they preferred to experience the mosque, 12 out of 26 interviewees explained that they prefer the experience to be "visual." For example, one respondent described how viewing the Islamic prayer service was desirable: "It's exciting to watch the worshippers visually and see the people walking hastily to pray, the drive, solemnity. It's so amusing to see them kneeling and touching the floor with their hands. It was so tempting that I couldn't help not to try it myself" (UK respondent). The above quote also supports Shackley (2001) and Orekat's (2016) argument that most visitors, whether they are secular or religious, show an interest in the religious activities of the site, and a willingness to participate in the religious experience.

Icons of religious "difference" were also found to be a significant part of what respondents preferred to view. This is mainly due to the fact that secular tourists are usually interested in the religious heritage values and iconic or distinct cultural artifacts of the site even in cases when such a site has no religious meaning for them (Badone, Roseman, 2004; Collins-Kreiner, Gatrell, 2006; Hyde, Harman, 2011; Orekat, 2016; Shackley, 2001). Bond (2013) and Eade (1992) argue that a sacred site itself may be deemed a site of attraction if it provides the secular visitor with unique and exceptional cultural or religious artefacts. In fact, of the experiences gained by respondents, the azan (call to prayers), congregational prayers, women's praying area and architectural design were reported to be the aspects that a number of respondents found most interesting because they saw them as representing "something different."

Besides, the findings suggest that the experience of secular visitors at sacred sites ought also to be seen in terms of reinforcing the "difference" between two religions. As one respondent explained, "I've noticed the design is different from the church. The mosque doesn't have any images of people like the Prophet, his mother or his companions. I only noticed geometrical motifs and Arabic inscriptions on the wall. But when you go to churches you will always see an image of Christ, Virgin Mary or saints on stained glass windows" (Dutch respondent). Another respondent noted, "I've heard the azan once during my two hour tour. It's different than a church [bell] ringing. I watched also some praying Muslims sitting on the floor repeating the words after the caller as they listen to him. This is unique. You will not find such scenes in churches" (French respondent). When these respondents were further prompted as to what they meant by 'different', they used terms such as "rare," "out of the ordinary," "unusual," "iconic,' "unique" and "will not see it at churches" to describe the kinds of experiences they preferred. This potentially confirms Orekat's (2016) conclusion that some religious sites provide secular and religious visitors with uniqueness, originality, genuineness and unfamiliar experiences. Rodrigues and McIntosh's (2014) study showed similar results, where a number of their respondents at a Catholic monastery in New Zealand reported a certain difference from other Christian monasteries, such as gender equality between males and females and the opportunity given to visitors to participate in all activities at the site. It could be argued that secular visitors revel in the uniqueness and otherness of religious sites and activities, as that presents them with a different experience as compared to their familiar sacred places. In other words, these respondents may belong to Cohen's experiential (1979) mode in that the mosque may offer them other experience (an unfamiliar faith system) different from their normal religious context.

The gaze on religious signs of otherness likewise drove respondents to photograph and selectively sample certain experiences to promote enjoyment. Respondents' desire to view icons of religious "difference" can be further evidenced in respondents' reported preferences for taking photographs of "unfamiliar religious scenes" and "certain symbols" (Figure 3). 
Comments made by respondents reinforce Orekat's (2016) argument that secular visitors at religious heritage sites tend to consume what they see as identifiable and unique symbols of a particular religion: "After the guided tour we wandered around the courtyard and took some photos of groups of students who were sitting with their sheikhs under the long pillars surrounding the courtyard chanting Qur'an loud and swaying their heads forwards and backwards. It's a unique experience and different from what most European Christians will do in the church" (Swedish respondent); "I was particularly interested in taking photos of the Mihr$a b$ wall in the mosque that gives you the direction to Mecca for praying. For me personally, it's an iconic symbol and made me think about the church altar where you turn toward the east. The Mihrab is plain, but the altar is often covered with a fine fabric and has special objects on it like candles and crosses" (Italian respondent). As such, it could be suggested also that by gazing on icons of religious "difference" and photographing unfamiliar signs, the respondents sought to negotiate or compare their preexisting experiences of the church with what they encountered at the mosque so that upon consumption, their own visualized version of the mosque became inherently meaningful to them.

Respondents' attraction to the icons of religious "difference" and their desire to take photos were confirmed by visitor observations. A number of respondents who spent some time around the open courtyard were occupied looking intently at the Arabic inscriptions on the wall and taking photos in front of or near the Mihrab and the pulpit where the prayer leader stands to deliver sermons. This also provides some level of support for divergence scholars who observed that secular visitors behaved differently from the religiously motivated visitors owing to their secular motivation and activities (Collins-Kreiner, Gatrell, 2006; Shackley, 2001; Shinde, Rizello, 2014). For example, the present study showed further evidence which potentially confirm the secular dimension of the visit in the sense of non-religious and profane activities (for example, gazing and taking photos) at sites considered as sacred.

\section{Personal interaction}

The dimensions of experience discussed above provide further evidence about how respondents preferred to gain an understanding of the site. In particular, it could be argued that respondents' appreciation of the site and Islam centered around a preference for personal interaction with the sheikhs. Previous studies of visitors' experiences at religious sites have provided increasing evidence that secular visitors desire direct contact with spiritual or faith guides through genuine interaction (Bond, 2013; Orekat, 2016; Rodrigues, McIntosh, 2014; Wong, et al., 2013). Indeed, respondents in the present study mentioned that "personal interaction with the sheikh" and "hands-on experience" was also an important part of experiencing the site and learning about Islam. For example, respondents commented that, "I enjoyed the personal interaction with the sheikh because you learn about the site and Islam straight from the horse's mouth, I mean from the sheikhs themselves and that knocks down negative stereotypes about Muslims" (UK respondent); "He [the sheikh] was warm and friendly, has a great sense of humor and taught us lots about the mosque and Islam. So we all felt comfortable asking questions and learning new stuff and also sharing with him what we know about Islam" (Swedish respondent); "Yeah, he [the sheikh] let us attend one of the prayer services and I was stunned by the act of devotion I had just seen. For me, it was a hands-on experiences not just something you see on TV or YouTube. It's special, more meaningful" (USA respondent). As such, personal interaction with the sheikh was perceived to include the opportunity for a "meaningful" encounter and "the opportunity to get to know Muslims." This kind of interactive experience matched 
the comment voiced by one of the sheikhs: "One of my strategies is to interact with them. The tour has to be an interactive relationship, not just one way. I ask them about Christianity and Judaism and talk to them about acts of worship. They become curious and very enthusiastic with their questioning" (Sh. 104). This is in line with findings of Kuo (2007) who pointed out that mosque guides are in fact engaged in cross-cultural interpretation of facts about Islam and Muslim traditions in such a way that the information is understandable to their foreign visitors. Visitor observation findings were consistent with these comments, as several visitors initiated informal conversations with the sheikhs about different topics and the sheikhs also tended to engage visitors with questions. Besides, there were particular symbols and areas in the mosque (i.e. Mihrab, crescent and women's praying area) that attracted visitors' attention and seemed to provoke a few short conversations and interactions with the sheikhs.

A few respondents commented on the "difficulty in having this personal contact with Muslim guides" as the opportunities are not currently easily available. One respondent commented on how they, "... had to search for information about visiting the mosque and it was not easily available for us. There are very few brochures and just only one website. Not a lot of tours. It's difficult to do it on your own" (French respondent); "We really liked this type of interactive tour but it's not easy to book such tour. Egypt travel agencies and tourism authorities don't promote the mosque well" (German respondent). As such, respondents prefer to visit the mosque and interact with Muslim guides but they currently do not know how to organize this. Indeed, Kamil (200o) has similarly concluded that religious tourism consumption experiences in Egypt are hardly based on ease and convenience of access and as such, tourists do not venture widely for experiences and make their way to religious sites. Along the same lines, most respondents stated that in their experience of the site, they preferred to have a "longer" experience rather than a "brief exposure," thus further reinforcing the meaningful nature of consumption. The main reason given for this was that it was felt that "two hours is just not enough to be immersed in the spiritual setting." Comments made by respondents included, "longer is better"; "short tour duration; I did not have enough time to enjoy the Islamic atmosphere"; "the tour would have been better if it was a bit longer." As such, respondents' preferences for "longer" rather than "brief" experiences of the mosque appear to confirm that tourists' seek interactive and personally meaningful experiences.

\section{Conclusion and research implications}

Sacred sites normally have multiple religious, spiritual, educational, historic and cultural values. This makes such places ideal destinations for visitors with different motivations. While some of these motives are religious, other motivations are secular and related to visitors' desire to learn about these places and their cultures or to visit them out of simple curiosity and leisure purposes. Accordingly, sacred sites offer their visitors a unique experience, particularly for those who visit for non-religious motives (De Sousa, 1993; Graburn, 1989; Katić, 2014; Rodrigues, McIntosh, 2014; Vukonic, 1996). Hence, the current research employed the qualitative approach to address the gap in the previous literature regarding understanding non-Muslim visitors' motives and experiences at Islamic sites, particularly Al-Azhar Mosque in Egypt.

The present study enables tourism scholars to look beyond Muslim visitors' motivations and experiences when visiting holy sites, and begin to address the perspectives of non-Muslim visitors. All respondents in the current research were non-Muslim, Western visitors, and their experiences revolved around three central secular dimensions, namely "curiosity and 
learning more about Islam and its heritage sites," "taking photos and gazing on icons of religious difference" and "personal interaction." This study has strongly reaffirmed the findings of other studies that visitation to sacred sites can take various forms which are not necessarily related to religion.

The findings of the study reinforce the conceptual separation of religious and secular visitors at religious sites. Respondents exhibited secular behaviors (i.e. taking photos and gazing on icons of religious difference) and desired to fulfill predominantly secular motives rather than religious motives in visiting the mosque. Thus the respondents' motives and experiences corresponded largely to the divergence paradigm of religious tourism. Divergence theorists (Cohen, 1979; De Sousa, 1993; Shackley, 2001) noted that secular visitors are different from their religious counterparts since they have strong secular motives (i.e. artistic, architectural, historical, sightseeing, cultural, educational, curiosity or leisure purposes) and their trip or visit is part of the secular experience. In spite of the views of mosques as sacred sites for prayers and community centers (e.g Bader, 2012).), today's mosques could also allow a number of secular experiences. These experiences may range from informal learning, or viewing iconic images and taking photos, to personal interaction. In the views of both visitors and the Al-Azhar mosque management, the site can be sacred and secular simultaneously.

The findings of the study are significant for identifying non-Muslim consumer demand for mosque-visiting and for assessing non-Muslim visitors' appreciation of Islamic sites. Mosque-visiting could be an important resource-based objective, where non-Muslim visitors can be viewed as potential market segments. Unlike Muslim visitors, worship is not part of these visitors' desire or experience. However, non-Muslim visitors' experiences in the mosque resemble visitor experiences in non-religious settings - learning about, seeing, and taking photos of something different from their usual experience. In addition, some visitors may be particularly interested in mosque-visiting to get an alternative perspective to the stereotypes of Muslims and Islam in Western countries. By better understanding their non-Muslim visitors and the wider roles the mosque may play in their experiences, mosque management can reconsider their approach to non-Muslim tourists, as well as rethink the mission and goals of the site.

In particular, the findings suggest that tourism marketers and mosque management should see mosque visiting as playing an important role in mediating the relationship between Islam and the non-Muslim visitor. Such tourism is mutually beneficial to the host site, the non-Muslim visitor, and potentially the larger global community. In the current study, sheikhs and non-Muslim visitors perceived the guided tour experience positively because they saw it as a channel for visitors to gain an increased understanding of and appreciation for Islam, its followers and its rituals, which may help to dispel misconceptions about Islam and diminish Islamophobia. Some secular visitors seek opportunities to visit mosques to learn about Islam from the Muslims themselves in a meaningful manner. The sheikhs (Muslim guides) were particularly significant for respondents during the visit as the sheikhs were able to connect the visitors with the site and inform them about Islam.

Despite visitors' reported preferences for genuine interaction with sheiks and worshippers, the brief nature of their religious tourism consumption was felt to be a barrier to gaining meaningful experiences. As such, a longer tour duration that allows both visitors and sheikhs to communicate and interact more in a meaningful manner, may constitute an appropriate development option to maximize the visitor experience, thus affecting the likelihood of religious tourism encounters to be mutually beneficial for host and visitor alike. Likewise, mosque management could consider giving non-Muslim visitors the opportunity to experi- 
ence the religious rituals at the mosque (i.e. possibility to witness Al-Jumu'a (Friday) prayer or Eid al-Adha (Festival of the Sacrifice) prayer in English) in order to provide authentic and meaningful experiences.

All in all, based on visitor responses, there is a need for more extensive promotion of opportunities for Islamic tourism experiences. Respondents commented, unprompted, that there ought to be more advertising of opportunities to experience mosques in Egypt, suggesting that some non-Muslim visitors perceived a lack of promotion and opportunities for such experiences. Some of the respondents described having great difficulties in acquiring the necessary information to join the mosque tour. Thus, while other non-religious tourism activities are widely advertised in Egypt (i.e. Safaris, diving, eco-tourism, visiting pyramids and museums, as well as beach resorts along the northern coast and Red sea), non-Muslim tourists who wish to visit a mosque currently may need to go to great lengths to obtain the necessary details and even then, have few options (Kamil, 200o). Despite the lack of marketing by travel agencies and tourism authorities, in fact, the mosque management and the guiding sheikhs themselves appear to welcome secular tourism. Hence, mosque-visiting needs to be more actively developed and promoted for the non-Muslim market. Public bodies should actively promote the development of mosque-visiting as part of the overall tourism experience.

The study of the motivations, perceptions and experiences of non-Muslim visitors at mosques is still in its early stages. Future research ought to consider the motivations and experiences of non-Muslim visitors at different mosques in Egypt and the Arab world. This may serve to verify the significance of the three central secular dimensions, namely "curiosity and learning more about Islam and its heritage sites," "taking photos and gazing on icons of religious difference" and "personal interaction." Another area for future research is to compare the expectations and experiences of Muslim and non-Muslim visitors at the mosque. Such a study can give insight into what these different types of groups do throughout the course of their mosque visit and explore their experiences in their own terms, including their on-site interactions. Finally, as has been encouraged in other studies of visitor experiences at religious sites (i.e. Bond, 2013; Orekat, 2016), the findings of this study using the qualitative approach can be complemented by quantitative study to substantiate the current research findings.

\section{Acknowledgements}

The authors would like to thank the sheikhs and visitors who freely gave of their time to share their views and experiences with us about the Al-Azhar Mosque.

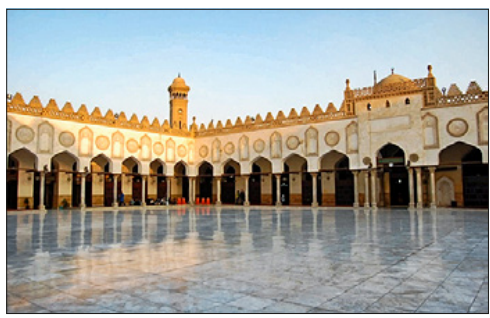

Figure 1. The large open air courtyard (sahn).

Photo taken by Author, June 2014

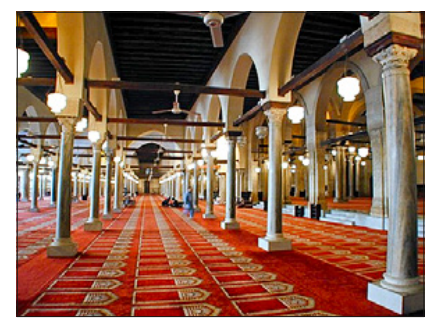

Figure 2. Interior of the AlAzhar Mosque: prayer hall (qibla).

Photo taken by Author, July 2014. 

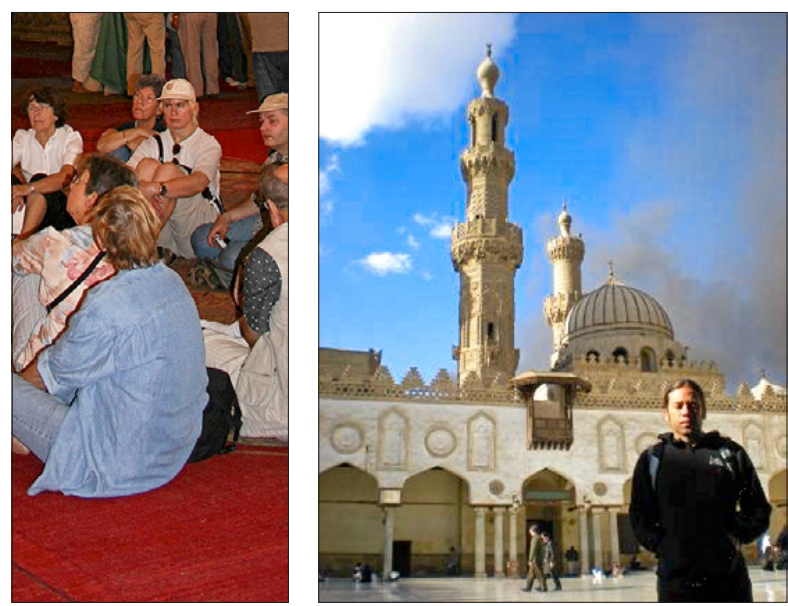

Figure 3. The image on the left shows tourists sitting on the floor, listening to the sheikh's explanations; the right image shows a tourist being photographed in front of or near the two elegant minarets with crescents at the top.

Photo taken by Author, June 2014.

\section{References}

Addison, E. 2004. The Roads to Ruins: Accessing Islamic Heritage in Jordan, in Y. Rowan and U. Baram (Eds.), Marketing Heritage: Archaeology and the Consumption of the Past, pp. 22948. Walnut Creek, CA: Altamira Press.

Alderman, D. 2002. Writing on the Graceland Wall: On the Importance of Authorship in Pilgrimage Landscapes. Tourism Recreation Research 27, 27-33.

Al Sayyad, N. 2013. Histories of a City. Belknap Press.

Al-Shuwekhi, A. 2014. Tourism ministry to launch campaign to encourage Europeans to visit Egypt. Daily News, retrieved May 14, 2016, from http://www.dailynewsegypt. $\mathrm{com} / 2014 / 07 / 21 /$ tourism-ministry-launch-campaign-encourage-europeans-visit-egypt/

Babbie, E. 2004. The Practice of Social Research (10 ed.). Belmont, CA: Thomson and Wadsworth Press (10 ed.). Belmont, CA: Thomson and Wadsworth Press.

Bader, M. A. 2012. Religious Tourism in Jordan:Current situation, future developments and prospects A case study on Islamic and Christian holy sites. Published Doctorate Thesis, The Catholic University of Eichstaett-Ingolstadt (KU).

Badone, E., Roseman, S. 2004. Intersecting Journeys: The Anthropology of Pilgrimage. University of Illinois Press.

Badone, E., Roseman, S. 2004. Intersecting Journeys: The Anthropology of Pilgrimage and Tourism. University of Illinois Press. USA.

Battour, M., Ismail, M. N. 2016. Halal tourism: Concepts, practises, challenges and future. Tourism Management Perspectives 19, 150-154.

Behling, O., Law, K. S. 200o. Translating questionnaires and other research instruments: Problems and solutions (Paper Series on Quantitative Applications in the Social Sciences 07-133). Thousand Oaks, CA: Sage Publications. 
Behrens-Abouseif, D. 1989. Islamic Architecture in Cairo: An Introduction. New York: E.J. Brill Koln.

Bhuiyan, H., Chamhuri, S., Ismail, S., Ehsan, D. 2011. Potentials of Islamic Tourism: A Case Study of Malaysia on East Coast Economic Region. Australian Journal of Basic and Applied Sciences 5(6), 1333-1340.

Blaxter, L. H., Tight, M. 1996. How to Research. Buckingham, Bristol: Open University Press.

Bond, N. 2013. Searching for Meaning: Exploring Pilgrimage and Religious Heritage. Unpublished Doctorate Thesis, The University of Queensland, Australia.

Cohen, E. 1979. A phenomenology of tourist experiences. Sociology 13(2), 179-201.

Cohen, E. 1992. Pilgrimage centres: Concentric and Excentric. Annals of Tourism Research 19(1), 33-50.

Collins-Kreiner, N. 2010a. Current Jewish pilgrimage tourism: Modes and models of development. Tourism 3(3), 259-270.

Collins-Kreiner, N. 2010b. Researching Pilgrimage. Continuity and trasformations. Annals of Tourism Research 37, 440-456.

Collins-Kreiner, N. 2010c. The Geography of Pilgrimage and Tourism: Transformations and Implications for Applied Geography. Applied Geography 30(1), 153-164.

Collins-Kreiner, N., Gatrell, J. 2006. Tourism, heritage and pilgrimage: the case of Haifa's Baha'i Garden. Journal of Heritage Tourism 1(1), 32-50.

Collins-Kreiner, N., Kliot, N. 20oo. Pilgrimage tourism in the holy land: the behavioral characteristics of Christian pilgrims. GeoJournal 50(1), 55-67.

Corbetta, P. 2003. Social Research Theory, Methods and Techniques. Clevedon, Buffalo: Channel View Press.

Creswell, J. 2009. Research Design: Qualitative, Quantitative, and MixedMethods Approaches. Sage Publications, Inc.

De Sousa, D. 1993. Tourism and Pilgrims: Tourists or Pilgrims? Contours 6(2), 4-8.

Decrop, A. 1999. Qualitative research methods for the Study of Tourist Behaviour. In A.Pizam, \& Y. Mansfield (Eds.), Consumer Behaviour in Travel and Tourism (pp. 335-365). Binghamton: The Haworth Press.

Di Giovine, M. 2011. Pilgrimage: Communitas and Contestation, Unity and Difference - An introduction. Tourism Review 59(3), 247-269.

Eade, J. 1992. Pilgrimage and tourism at Lourdes, France. Annals of Tourism Research 19, 18-32.

Ellinger, A. D., Watkins, K. E., Marsick, V. J. 2005. Case Study Research Methods. In A. S. Robert, F. H. Ellie (Eds.), Research in organizations: foundations and methods of inquiry (pp. 327-350). San Francisco: Berrett-Koehler Publishers.

Gerrard, L. 2010. Your Dreams: Spiritual Messages in Pajamas. Llewellyn Worldwide Press.

Goulding, C. 2002. Grounded theory: a practical guide for management, business andmarket researcher (1 ed.). London: Sage Publications, Inc.

Graburn, N. 1989. Tourism: The Sacred Journey. In S. VaIene (Ed.), Hosts and Guests:The Anthropology of Tourism (pp. 17-32). University of Pennsylvania Press, Philadelphia.

Gunlu, E., Okumus, F. 2010. The Hajj: Experience of Turkish Female Pilgrims / Fevzi. In S. Noel, J. Jafar (Eds.). UK: Emerald Group Pulblishing Limited.

Hall, C. 2006. Travel and Journeying on the Sea of Faith: Perspectives from Religious Humanism. In O. Dally, T. Dallen (Eds.), Tourism, Religion and Spiritual Journeys (pp. 64-77). Routledge, London.

Haq, F., Wong, H. Y. 2013. Branding Islamic Spiritual Tourism: An Exploratory Study in Australia and Pakistan. Islamic Management and Business 5(11), 154-162. 
Heaton, J. 2004. Reworking Qualitative Data. London: Sage Publications Ltd.

Hyde, K. F., Harman, S. 2011. Motives for a secular pilgrimage to the Gallipoli battlefields. Tourism Management 32, $1343-1351$.

Jafari, J., Scott, N. 2014. Muslim World and its Tourisms. Annals of Tourism Research 44, 1-19. Kaelber, L. 2006. Paradigms of Travel. From Medieval Pilgrimage to the Postmodern Virtual Tour. In D. Olsen, D. Timothy (Eds.), Tourism, Religion and Spiritual Journeys (pp. 49-63). Routledge, London.

Kamil, J. 200o. Religious tourism as big business. Retrieved July 16, 2016, from http://weekly. ahram.org.eg/Archive/200o/469/tr2.htm

Katić, M. 2014. Pilgrimage and/or Tourism in Bosnian Croat Shrine of Kondžilo. In M. Katić, K. Tomislav, M. Mike (Eds.), Pilgrimage and Sacred Places in Southeast Europe: History, Religious Tourism and Contemporary Trends (pp. 145-158). Wien and Berlin: Lit Verlag.

Liebersohn, H. 1996. Recent Works on Travel Writing. Journal of Modern History 68, 617-628.

MacCannell, D. 1973. Staged authenticity, arrangements of social space in tourist settings. American Journal of Sociology 79(3), 589-603.

MacCannell, D. 1999. The Tourist: A New Theory of the Leisure Class. California Press, California.

Margry, P. 2008. Shrines and Pilgrimage in the Modern World: New Itineraries Into the Sacred. Amsterdam University Press, Amsterdam.

Marine-Roig, E. 2015. Religious Tourism versus Secular Pilgrimage: The Basilica of La Sagrada Família. International Journal of Religious Tourism and Pilgrimage 3(5), 25-37.

McIntosh, A. J. 1998. Mixing Methods: Putting the Tourist at the Forefront of Tourism Research. Tourism Analysis 3, 121-127.

McIntosh, A. J., Prentice, R. 1999. Affirming Authenticity: Consuming Cultural Heritage. Annals of Tourism Research 26(3), 589-612.

McIntosh, A. J., Siggs, A. 2005. An exploration of the experiential nature of boutique accommodation. Journal of Travel Research 44(1), 74-81.

Neumann, J. 2014. Tours of Mosque Promote Understanding. Chicago Tribune. Retrieved August 6, 2016, from http://articles.chicagotribune.com/2014-02-10/news/ct-american-islamic-association-tl-ssw-0213-20140210_1_mosque-muslims-american-islamic-association

Nolan, M. L., Nolan, S. 1992. Religious sites as tourism attractions in Europe. Annals of Tourism Research 19(1), 68-78.

Olsen, D. 2013. A Scalar Comparison of Motivations and Expectations of Experience within the Religious Tourism Market. International Journal of Religious Tourism and Pilgrimage 1(1), 41-61.

Orekat, F. 2016. Understanding Visitors' Experiences at Religious Heritage Sites: A Case Study from Jordan. Doctorate Thesis, University of Sydney, Australia.

Ozkan, C. 2013. The Convergence or Divergence of Pilgrimage and Tourism in Modern China. International Journal of Social Inquiry 6, 118-138.

Patton, M. Q. 2002. Qualitative Evaluation and Research Methods (2 ed.). Newbury Park, CA: Sage Publications, Inc.

Polkinghorne, D. E. 2005. Language and Meaning: Data Collection in Qualitative Research. Journal of Counseling Psychology 52(2), 137-145.

Poria, Y., Butler, R., Airey, D. 2003. The core of heritage tourism, distinguishing heritage tourists from tourists in heritage places. Annals of Tourism Research 30(1), 238-254. 
Raj, R., Bozonelos, D. 2015. Pilgrimage Experience and Consumption of Travel to the City of Makkah for Hajj Ritual. International Journal of Religious Tourism and Pilgrimage 3(1), 38-45.

Reader, I., Walter, T. 1993. Pilgrimage in Popular Culture. London: The Macmillan Press.

Rinschede, G. 1992. Forms of Religious Tourism. Annals of Tourism Research 19(1), 51-67.

Rodrigues, S., McIntosh, A. 2014. Motivations, experiences and perceived impacts of visitation at a Catholic monastery in New Zealand. Journal of Heritage Tourism 9(4), 271-284.

Rojo, D. 2007. Religious Tourism: The Way to Santiago. Unpublished Masters Thesis, Bournemouth University.

Rubin, H., Rubin, I. 2005. Qualitative interviewing: the art of hearing data (2 ed.). Sage Publications, Inc.

Ryan, C. 1995. Researching Tourist Satisfaction: issues, concepts, problems. London: Routledge Press.

Santos, M. 2002. Pilgrimage and Tourism at Santiago de Compostela. Tourism Recreation 27(2), 41-50.

Santos, M. 2003. Religious Tourism: Contributions Towards a Clarification of Concepts. In M. F, \& Edwards (Eds.), Religious tourism and pilgrimage (pp. 27-42). Portugal: Tourism Board of Leiria.

Shackley, M. 1998. A Golden Calf in Sacred Space: The Future of St Katherine's Monastery, Mount Sinai (Egypt). International Journal of Heritage Studies 4, 123-134.

Shackley, M. 2001. Managing Sacred Sites: Service Provision and Visitor Experience. London: Continuum.

Shackley, M. 2002. Space, sanctity and service; the English Cathedral as heteropia. International Journal of Tourism Research 4(5), 355-365.

Shafaei, F., Mohamed, B. 2015. Malaysia's branding as an Islamic tourism hub: An assessment. Malaysia Journal of Society and Space 11(1), 97-106.

Shinde, K., Rizello, K. 2014. A Cross-cultural Comparison of Weekend-trips in Religious Tourism: Insights from two cultures, two Countried (India and Italy). International Journal of Religious Tourism and Pilgrimage 2(2), 17-34.

Shuo, Y. S., Ryan, C., Liu, G. 20o9. Taoism, Temples and Tourists: The Case of Mazu Pilgrimage Tourism. Tourism Management 30, 30, 581-588.

Smith, V. L. 1992. Introduction. The quest in guest. Annals of Tourism Research 19(1), 1-17.

State Information Service. (2016, May 15). Retrieved August 30, 2016, from http://www.sis.gov. eg/Story/1224?lang=en-us

Stephenson, M. 2014a. Deciphering 'Islamic hospitality': Developments, challenges and opportunities. Tourism Management 40, 155-164.

Stephenson, M. 2014b. Tourism, development and 'destination Dubai': cultural dilemmas and future challenges. Current Issues in Tourism 17(8), 723-738.

Suntikul, W. 2008. The Impact of Tourism on the Monks of Luang Prabang, In: 16th ICOMOS General Assembly and International Symposium: 'Finding the spirit of place - between the tangible and the intangible', 29 sept - 4 oct 2008, Quebec, Canada.

Swarbrooke, J., Horner, S. 1999. Consumer behaviour in tourism. Oxford: Butterworth-Heinemann.

Temporal, P. 2011. Islamic Branding and Marketing: Opportunities and Challenges. Retrieved August 3, 2016, from http://www.europeanfinancialreview.com/?p=2829

The Egyptian Tourism Authority 2012. "We're Egypt" campaign launched at the WTM in London. Retrieved April 23, 2016, from: www.egypt.travel 
The Egyptian Ministry of Tourism (2010/2015). Egypt Tourist Arrivals | 2010-2015 | Data | Chart, and Forecast [Arabic]. Cairo, Egypt.

The Egyptian Ministry of Tourism 2012. Tourism Statistics \& the Development of Tourism.

Turner, V. \&. 1978. Image and pilgrimage in Christian culture. New York: Colombia University Press.

UNWTO 2014. September 17. World Tourism Organization UNWTO. Retrieved 8 23, 2016, from World Tourism Organization UNWTO: http://media.unwto.org/press-release/2014-09-16/ first-unwto-international-congress-tourism-and-pilgrimages-explores-link-be

Urry, J. 2001. The Tourist Gaze (2 ed.). London: Sage Publications.

Vukonic, B. 1996. Tourism and Religion. London: Elsevier.

Vukonic, B. 2002. Religion, Tourism and Economics: A Convenient Symbiosis. Tourism Recreation Research 27(2), 59-64.

Wong, C. 2016. The Big Buddha of Hong Kong: an accidental. Tourism Geographies 18(3). Retrieved June 17, 2016, from http://www.tandfonline.com/doi/full/10.1080/14616688.2016 .1158204

Wong, C., McIntosh, A., Ryan, C. 2013. Buddhism and tourism: Perceptions of the monastic community at Pu-Tuo-Shan, China. Annals of Tourism Research 40(1), 213-234.

Yin, K. R. 2003. Case study research: Design and methods (Applied Social Research Methods Series) (2 ed., Vol. 34). London: Sage Publications Ltd.

Zamani-Farahania, H., Eidb, R. 2016. Muslim world: A study of tourism \& pilgrimage among OIC Member States. Tourism Management Perspectives 5, 144-149. 